three in the previous year, representing a total approved capital of $£ 74 \cdot 2$ million, of which $£ 45,753,000$ was deployed at the end of the year. Of these projects, sixteen are in the Caribbean, eight in the Far East, fifteen in East Africa, seven in Central Africa, twelve in High Commission Territories, and eight (including one in Ghana) in West Africa. Functionally, thirteen projects and 18.6 per cent of deployed capital were in agriculture; six projocts and 4.5 per cent capital in animal projects; eight projects and $7 \cdot 0$ per cent capital in factories ; one project and 0.3 per cent capital in fisheries; four projects and $11 \cdot 2$ per cent capital in forestry; two projects and 0.5 per cent capital in hotels ; nine projects and 12.7 per cent capital in minerals; eight projects and 12.5 per cent capital in property and housing; nine projects and 27.5 per cent eapital in power ; and six projects and $5 \cdot 2$ per cent capital in transport and communications.

While the projects controlled by the Corporation are in much better shape as revenue-earners than before, the report points out that the three outstanding issues in 1955 are still unsettled. The 'special losses' on pre-1951 commitments abandoned wholly or in part were assessed last year at $£ 8,020,441$, and even if the Secretary of State's power to waive interest is exercised in full, it does not relieve the Corporation of its obligation to repay the 'special losses' capital. 'The load cannot be carried by other projects, which can probably do no more than service their own capital, particularly if, as has been argued by the Colonial Office, the Corporation should not be allowed to embark on undertakings for which alternative finance is available. Lord Roith points out trenchantly that, on this argument, it would become impossible for the Corporation to associate with credit-worthy borrowers, who obviously would allow neither the Corporation nor the Government to test the market nor provide any certificate likely to damage their credit.

On the interest question, the report points out that, borrowing at the present level $(4 \cdot 25$ per cent for short-term, 5 per cent for medium-term and 5 per cent for long-term loans, fixed on February 16 , 1957 - compared with 4 per cent, 5 per cent and 4.75 per cent at January 17,1956$)$, now projects must show equivalent high returns, and the Corporation is faced with completing existing jobs with money now costing almost double the rate at which the projects were budgeted. This policy slows down Colonial development more than is necessary or desirable, and in March 1956 the Corporation was presented with a new schedule of annuities payable, revoking the previously agreed interest-free period to March 31, 1957, and involving additional interest of more than $£ 957,000$.

The third outstanding issue relates to the powers of the Corporation, and although the Overseas Resources Development Act, 1956, which became law on August 2,1956 , removed some doubts as to the validity of past activities, it created fresh doubts, for example, as to the validity of Southern Rhodesian undertakings. Lord Reith also offers a strong protest at the exclusion of the Corporation from territories emerging into independence. The Corporation was informed in August that the Government did not contemplate the starting of new projects after a Colony became independent, and in November the Corporation was told that certain new schemes for Ghana and Malaya were to be arbitrarily excluded, while a clause in the Ghana Independenee Bill excluded
Ghana from the term 'colonial territories' in the Overseas Resources Development Acts, 1948 to 1956. Both Ghana and Malaya have protested at the loss of the Corporation's help, and Lord Reith urges that it is common sense that the Corporation's services should be available to both emerging and emerged. members of the Commonwealth.

\section{MIGRATIONS OF HUMPBACK WHALES}

$T$ $\mathrm{HE}$ migrations of whalebone whales in the southern hemisphere have long been of interest, and those of the humpback whale (Megaptera novaeangliae) were among the first to be recognized by the whalers working at South Ceorgia and on the African coasts in the early years of this century. In later years Australian, British, Norwegian and other workers assembled further evidence of these migra. tions, and their conclusive demonstration between Antaretic waters and the north-west coast of Australia, and the waters off Madagascar, was an immediate result of the whale-marking undertaken in the Southern Ocean by the Discovery Committee in the 1930's. W. H. Dawbin has now extended our knowledge of the movements of humpback whales in the Pacific Ocean by his study of records of some 9,000 individuals of this species in New Zealand coastal waters (Trans. Roy. Soc. N.Z., 84, 1, 147 ; 1956). These records, which include the catch statistics of shore whaling stations; sightings by lighthouse keepers, coastal vessels and aircraft pilots; and data from old logbooks, diaries, etc., have been combined to give a clear picture of the northward and southward migration routes. Northbound whales pass mainly along the east coasts of New Zealand, but there is one group passing through Cook Strait to the west coast of North Island, and another moving around the south-west corner of South Island. South-bound whales pass mainly down the west coasts, but some follow the east coast of North Island as far as East Cape. Records of 'out of season' whales sighted in January, February and March are of interest in view of the evidence which is accumulating of the presence of some whalebone whales in the warmer latitudes when the bulk of the population has migrated south to the Antarctic.

The seasonal variation in the date and duration of the migration and in the relative abundance of whales passing in different years has been studied, and the rate of migration along the coast has been calculated at approximately 220 nautical miles a week in a direct north-south line. It is evident that this slow overall rate of advance is the result of frequent periods of rest and random movements on a large scale, since the cruising speed of humpback whales on passage has been observed to average 4-5 knots and it is known that individual animals may travel up to 500 miles at an average speed of more than 3 knots.

Dr. Dawbin is to be congratulated on the detailed. picture he has built up of the movements of this whale in New Zealand waters. More information about its migrations in the Pacific Ocean as a whole will come from his work in organizing the whalemarking programme, and the collection of observations of humpback whales among the island groups of the South Pacific.
S. G. Brown 